\title{
Business Strategies and Competitive Advantage: Evidence from Flour Mill Companies in Lagos State, Nigeria
}

\author{
Egwakhe, A. J., Falana, R. B., Asikhia, O. O., Magaji, N. \\ Department of Business Administration and Marketing, Babcock University, Ogun State, Nigeria \\ jegwakhe@gmail.com
}

\begin{abstract}
The authors argued from business strategies perspective to understand competitive advantage among homogenous producers. The population consisted of top and functional managers of flour mill companies in Lagos State, Nigeria. Cross sectional survey research design was adopted and primary data were collated and used. The research instrument was an adapted questionnaire. Its validity and reliability were statistically determined. Six hundred and twenty copies of the questionnaire were administered and 605 retrieved. Econometric equation was formulated and multiple regression analysis was employed for data analysis. Business strategies were found to have significantly affected competitive advantage. The study recommended product differentiation and portfolio diversification in order to achieve competitive advantage.
\end{abstract}

Keywords: Backward integration, Business development, Competitive advantage, Regrouping.

\section{Introduction}

Competitive advantage seems to be elusive and the strategic approaches to gaining and sustaining it differ across firms, industries and nations. This has brought polarization in option and divergence in perspectives, and prescriptions. The differential in approach and prescriptions unearth challenges as firms in diverse business operations struggle to determine the best-fit towards preventing strategic drift or flux. Competitive advantage further differs in meaning and terminology usage with concepts dealing with development and deployment of a set of attributes that allow competitors' outperformed (Nuryakin, 2018), industrial superiority (Porter, 1985) above industry average (1980), and excellence (Maury, 2018; Namada, 2018). The looseness in meaning and usage is equating competitive advantage with competitive success. Changes in the business world, hyper-competition, and language dynamism are imposing operational re-engineering in strategic reconfiguration to strengthen organization's capability to compete for limited customers and market share with products that meet and exceed customer's expectation (Sharma \& Singh, 2013).

The race among and between firms, is often centered on how do we survival for foreign and local competitive onslaught. For firms to gain advantage or success, the business strategies applied are commonly in tandem with the firms' strength, objectives, desired future, and the business environment. Researchers (Araghi, Nikoomaram \& Ghaffari, 2019; Bailey, Benson \& Bruner, 2019; Muda \& Erlina, 2019) have investigated business strategies with performance measures and achieved different results. Moravcikova, Krizanova, Kliestikova and Rypakova (2017) had associated business strategies practices with competitive advantage but the positive impact although significant, varies across constructs. The wealth of knowledge and the depth of managerial effect discovered in the aforementioned works might not suit some context due to economic differentials and methodological focus. In addition, the studies did not investigate the business strategy proxies entrenched herein and competitive advantage especially in Lagos State and the flour mill sector, therein, leaving unfilled academic gap in literature as to how business strategies influence competitive advantage within Nigerian flour mill sector.

The global competitiveness of Nigerian flour mill is evident in consumers' perception of lower quality vis-avis imported flour as observation in consumption and patronage favored foreign brands. As such, the Nigerian government had intervened to salvage the situation by closing borders and encouraging local investment in order to regain competitiveness according to Bala and Alhassan (2018) and Egbo (2018). The report of Flour Mills of Nigeria [FMN] (2019) and Obasaju, Olayiwola, Okodua and Adekunle (2019) suggest that the adoption of backward integration to control quality challenges and selective diversifications are necessary solutions to the impending doom of the sector. Noe, Hollenbeck, Gerhart and Wright (2017) shares similar position which Namada (2018) who identified product differentiation along quality, efficiency, innovation, and accountability as enablers of competitive advantage. However, Nithisathian, Wall, Thanitnan 
and Ponwiritthon (2018) found that business strategies negatively affected competitive advantage which Lawal.

Thompson and Thompson (2016) identified as weak effect on competitive advantage. Gakuya and Mbugua (2018) identify cost leadership strategy as the missing link for achieving competitive advantage and overall organizational performance. Nevertheless, the position of Giama, Mamaloukakis and Papadopoulos (2019) was that operational efficiency and organizational excellence are drivers of competitive advantage. Kwayu, Lal and Abubakre (2018), Geisler and Turchetti (2018) discovered that business strategies had little influence on competitive advantage. The polarization in perspective among scholars (Bailey et al., 2019; Kwayu et al., 2018) prompted the investigation into what drives competitive advantage. The objective of this study was to examine the effect of business strategies on competitive advantage with a focus on Lagos State, Nigeria Four Mills. The work is capable of deepening managers and stakeholders' insight and shapes their managerial capabilities in the sector as price-war, product cannibalism, and foreign products dominate the market with reasons less understood.

\section{Review of Related Literature}

Noe et al. (2017) defined competitive advantage as firms' ability to produce goods and services more efficiently than competitors. This definition infused waste elimination, cost reduction (Maury, 2018), and quality to denote the hallmark of operation which Namada (2018) had previously sustained. Jones, Harrison and Felps (2018) defined competitive advantage similar to firm's ability to produce goods or services that customers see as more valuable than competitors. Tincani and Travers (2018) added to the concept definition that competitive advantage is a set of a company's unique features, products and services that are perceived by the market as significant and superior to the competitors. The term strategy denotes means deployed towards achieving organizational goals and objectives (Zhou \& Wen, 2019). According to Mishra et al. (2019), strategy is the creation of unique and valuable position involving different sets of activities. Similarly, Majid, Yasir, Yasir and Javed (2019) portrayed strategy as a perceived long-range plan of a business, which provides and sustains shareholders value. Mac-Donagh et al. (2019) argued that strategy is the basic long-term goals and objectives of a firm and the adoption of the courses of action and the allocation of resources necessary for achieving the goals. Pereira et al. (2019) explained that it consisted of combinations of competitive moves and business approaches that managers employ to please customers, compete successfully, conduct operations and achieve organizational objectives.

In this paper, strategy is seen as means to an end with its proxies as cost leadership, market development, diversification, regrouping backward integration and product development. Cost leadership is about reducing cost, building quality into operation and producing the least expensive goods (Hunjra, Faisal \& Gulshion, 2018). Alkasim et al. (2018) defined cost leadership as the way in which firms charge lower price for their products than rivalry firms. Gakuya and Mbugua (2018) believed that cost leadership is the projected brand image of an organization with reference to cheapest goods or a provider of a particular products or commodities but with best value. Kharub, Mor and Sharma (2018) expanded the concept by describing cost leadership as creating low cost of operations within a niche. Jyoti, Arora and Kour (2017) argued that cost leadership is drawing customer's attentions towards company's products with least financial implication. Farzin, Yaghubipoor and Nekoui (2017) defined cost leadership as marketing products that is highly effective in gaining market share. Kiprotich, Gachunga and Bonuke (2018) viewed cost leadership as achieving competitive advantage through lowest cost of operation in the industry. Product differentiation as a strategy consists of creating differences in a firm's product which Ghiyasi (2017) defined in terms of innovation differentiation, brand image differentiation and positioning.

Lawal et al. (2016) added that it's about providing product to a discriminating segment of a market by offering product with excellent image and strong brand identification. Bui and Villiers (2017) believed that product differentiation creates a defensible position for overcoming competition. Wahal (2019) argued that product differentiation is investing heavily in research and development activities in order to increase their innovative capability and enhance their ability to keep-up with their competitors' innovations. Backward integration involves both mental and physical alertness, exploring opportunities, taking chances and risks in order to control price and raw materials sources (Camba, Mendez \& Werner, 2017). Ahmad, Iqbal and Ali 
(2018) defined backward integration as a business model whereby a company takes direct control of how its inputs are supplied. Jensen, Rust and Mackool (2018) argued that backward integration ensures that a firm produces inputs or segments of its supply chain. Backward integration is an approach of a company to increase its level of control on its inputs (Opolot \& Mpagi, 2017). The concept of market development as a construct was defined by Jones et al. (2018) as taking current products to new markets thereby opening up previously excluded market segments and distribution channels or entering new geographic markets.

Maury (2018) affirmed that it involves moving the present product into new geographical areas and expanding sales by attracting new markets. Anwar (2018) believed that market development is increasing sales by selling an existing product to a new market that was originally considered non-profitable for the organization. Kuik, Branger and Quirion (2019) argued that market development is getting into a new geographical market, creating new product dimensions like packaging, using new distribution channel or by creating a new market segment by offering different prices. Business diversification is a collection of individual businesses (Qamri, Haq \& Akram, 2015), which Cegarra, Jiménez, Garcia and Perez (2019) also defined as collection of businesses under one corporate umbrella. Axenbeck (2019) defined business diversification as competing with an array of different portfolios that may or may not be related. Wen, Xiao, Huang and Xia (2018) added to the concept as expanding business fields either to new markets, new products or both while retaining strong core businesses.

Guzman, Ocampo and Stiglitz (2018) defined business diversification as expanding firm's operations by adding markets, products, services or stages of production to the existing business. Regrouping as a construct is the fundamental change in staff number to increase financial structure and or designed to increase the company's financial value (Bodhanwala \& Bodhanwala, 2018). The study of Bryksina, Golovina and Legotin (2018) found that overall cost leadership strategy propels competitive advantage for an organization over rivalry firms. According to Pervan, Curak and Kramaric (2018) regrouping radically alters the contractual relationship with staff. Wahal (2019) argued that regrouping is increasing economic viability of the underlying business model by reducing staff strength. Nakatani (2019) believed that regrouping is an opportunity to end business cycle, recap the performance and outline a plan of success by restructuring staff. Lawrence, Crecelius, Scheer and Patil (2019) defined regrouping as an attempt to recast organizational structure, leadership, culture and reward systems that change cost competitiveness and quality.

Business Strategies and Competitive Advantage: Several studies (González-Rodríguez, Jiménez-Caballero, Martín-Samper, Köseoglu, \& Okumus, 2018; Namada, 2018) have discussed the interrelatedness between business strategies and competitive, advantage with varying empirical findings and conclusions. Empirical discussions on business strategies and competitive advantage have shown that there exists consensus amongst scholars (Distanont \& Khongmalai, 2018; Husgafvel, Linkosalmi, Hughes, Kanerva \& Dahl, 2018) in some situations and constructs. Isiavwe, Ogbari, Ogunnaike and Ade-Turton (2015) concluded that cost leadership strategy is useful for goals accomplishment but fundamentally drives competitive advantage. Nyaucho and Nyamweya (2015) shared the same position that cost leadership influences market price which enables sales volume increase, profit margin, service delivery, reduced operational costs and wastage, which Gregson and Andrew (2008) had previously established. Ordonez et al. (2018) added that competitive advantage is a derivative of cost reduction and operational excellence without comprising quality. Wijaya's (2018) approach to cost leadership and competitive advantage is similar to Akram, Sanaz and Mohammed (2018) that competitive advantage is derived from product differentiation along quality, efficiency, innovation and accountability. The assumption is that competitive advantage $(Y)$ position at a categorical time is a progenitor of business strategies $(X)$ deployed. The primary population was five flour mill companies which are Flour Mills of Nigeria Plc, Honeywell Flour Mills, Life Flour Mill Limited, Crown Flour Mills, and Dangote Flour Mills.

The selection of these companies was anchored on their operational performance, financial results, capacity utilization, employees' number, and market dominance in the sector. The top and functional managers were purposively selected since this group constituted the top-decision makers, members of the strategic development group, think-tank and the brain-bank of the companies. Ibidunni (2009) added to the debate but concentrated on product differentiation anchored on product re-engineering, logistics synergy, and intense marketing to achieve competitive advantage. From the views of Isiavwe et al. (2015), Akram et al. (2018), 
Lantos (2001) and Porter's (1980; 1985) cost leadership, differentiation, and regrouping are strategic recipes for competitive advantage. In addition, the synchronization of cost leadership and product differentiation enhances customer-centric operations and waste elimination, which are preconditions for competitive advantage. The market perspective to the interpretation of product differentiation was Galdeano-Gomez, Céspedes-Lorente and Martínez-del-Río's (2008) work that competitive advantage depends on a firm's ability to adapt to product features that are eco-friendly and customer focused. As such, Chiou, Chan, Lettice and Chung (2011) demonstrated that value addition and strategic alignment to environmental dynamism enables competitive advantage. The decision to adopt a cross-sectional design resulted from its ability to allow reliable data collection (Knottnerus, 2003), generate robust results (Groves et al., 2004) and valid scientific conclusion in knowledge creation.

\section{Methodology}

The paper is quantitative cross-sectional survey research design. It's, scientific application was justified by Ariguzo, Egwakhe and Adefulu (2019) along coexistence of possibilities in constructs association and causaleffect relationship. In addition, its strength revolves around its ability to capture respondents' perception at a categorical point in time (Heeringa, West \& Berglund, 2010). Evidences of its use are prevalent in Ariguzo et al. (2019), Haseeb et al. (2019), McKenney and Reeves (2018) and Tincani and Travers (2018). The total population of the selected top and functional managers was six hundred and seventy-eight, hence total enumeration sample technique was used. The decision to use total enumeration sample technique was based on (Groves et al., 2004), Heeringa et al. (2010) perspectives along size, traits, experience and knowledge of the phenomenon under investigation. A structured questionnaire was adapted from previous studies (Anyanwu \& Umeh, 2019; Boddy, McCalman \& Buchanan, 2018; Cassia \& Magno, 2019; Guzman, Ocampo \& Stiglitz, 2018; Maury, 2018; Nakatani, 2019; Ngwakwe \& Sebola, 2019; Qamri, Haq \& Akram, 2015) whose content, construct and criterion validity were established. The questionnaire is a Likert-type scale ranging from very high (6) to very low (1) on business strategy and competitive. A total of 620 copies of the questionnaire were administered to top and functional managers who were available and accessible during the four weeks of field-work. Six hundred and five copies were retrieved and were judged usable.

Model Specification: The assumption behind the work is that business strategies affect firms' competitive advantage in the flour mill sector. Zhou and Wen (2019) concluded that the deployment of business strategy enhances the possibility of achieving competitive advantage. Fifteen copies had errors in filling and were dropped from the work to prevent error in coding and analysis. It was on this premise that a mathematical model was elicited as $Y=f(X)^{\mathrm{n}}$. The $Y$ is the competitive advantage (CA) and $X$ with it proxies $\left(\mathrm{x}_{1}, \mathrm{x}_{2}, \mathrm{x}_{3}, \mathrm{x}_{4} \cdot \mathrm{x}_{5}\right.$, $\mathrm{x}_{6}$ ) as cost leadership (CL), product differentiation (PD), backward integration (BI), business development (BD), business diversification (BDI) and Regrouping (RG). The dynamism in business strategies (cost leadership, product differentiation, backward integration, market development, business diversification, regrouping) as unique means employed by organization determines a firm's competitive advantage or superior performance. This implies that the bundle of strategy deployed has direct effect on competitive advantage. The work therefore borrowed from the position of Kor and Mahoney (2004) that adopted business strategies $(X)^{\mathrm{n}}$ and it's $(X \ldots \ldots . . . X)^{\mathrm{n}}$ affect competitive advantage $(Y)$. This was expressed mathematically as $C A=\beta_{0}+\beta_{1} C L_{i}+\beta_{2} P_{i}+\beta_{3} B_{i}+\beta_{4} M_{i}+\beta_{5} B D_{i}+\beta_{6} R G_{i}+\mu_{i}$. The paper's apriori expectation was anchored on the premise that business strategies will have positive significant effect on competitive advantage. The ethical issues and the rules governing the conduct of research were respected and the data collected from the field were not manipulated to reflect otherwise.

\section{Findings and Discussion}

The results of the analysis are presented in Table 1 showing the effect of business strategies on competitive advantage of selected flour mill companies in Lagos State, Nigeria. The assumption of the work was investigated through multiple linear regression analysis. The results as shown, 
Table 1: Result of Analysis for Business Strategies on Competitive Advantage

\begin{tabular}{|c|c|c|c|c|c|c|c|}
\hline Model & B & Sig. & $T$ & $\begin{array}{l}\text { ANOVA } \\
\text { (Sig.) }\end{array}$ & $\mathbf{R}^{2}$ & Adju. $\mathbf{R}^{2}$ & F (df) \\
\hline (Constant) & 0.910 & 0.000 & 4.292 & \multirow{7}{*}{$0.000^{\mathrm{b}}$} & \multirow{7}{*}{0.388} & \multirow{7}{*}{0.382} & \multirow{7}{*}{$\begin{array}{l}63.153 \\
(6,597)\end{array}$} \\
\hline Cost Leadership & 0.095 & 0.057 & 1.910 & & & & \\
\hline Product Differentiation & 0.205 & 0.000 & 4.055 & & & & \\
\hline Backward Integration & 0.028 & 0.502 & 0.672 & & & & \\
\hline Market Development & 0.144 & 0.001 & 3.331 & & & & \\
\hline Business Diversification & 0.180 & 0.000 & 3.654 & & & & \\
\hline Regrouping & 0.173 & 0.000 & 3.704 & & & & \\
\hline $\begin{array}{l}\text { Predictors: (Constant), } \mathrm{R} \\
\text { integration, Product diffe } \\
\text { Dependent Variable: Com }\end{array}$ & $\begin{array}{l}\text { groupir } \\
\text { centiatic } \\
\text { petitive }\end{array}$ & $\begin{array}{l}\text { ost lea } \\
\text { antage }\end{array}$ & hip, Mz & developm & Busines & liversificat & Backward \\
\hline
\end{tabular}

Source: Field Survey, 2020

The $R^{2}$ value, which is the coefficient of determination $=0.388$, thus indicated that business strategies had weak positive and significant effect on competitive advantage in selected flour mill companies. The research model was multiple, as such the coefficient of multiple determination, adjusted $R^{2} 0.382, F(6,597)=63.153$, $p<0.05$ ) demonstrated that business strategies explained $38.2 \%$ changes in competitive advantage, while the remaining $61.8 \%$ could be attributed to other factors not included in this model. Also, the $F$-statistics $(d f=6$, $597)=63.153, p<0.05$ ) which revealed that the overall model was robust and significant in predicting the effect of business strategies on competitive advantage. The analysis revealed that four out of the six dimensions of business strategies had positive significant effect on competitive advantage. The result showed that product differentiation $(\beta=0.205, t=4.055, p<0.05)$, market development $(\beta=0.144, t=3.341, p<0.05)$, business diversification $(\beta=0.180, t=3.653, p<0.05)$.

Regrouping $(\beta=0.173, t=3.704, p<0.05)$ had positive and significant effect on competitive advantage. However, the other variables cost leadership $(\beta=0.095, t=1.910, p>0.05)$ and backward integration $(\beta=$ $0.028, t=0.672, p>0.05$ ) had positive but insignificant effect on competitive advantage among the selected flour mill companies. The result inferred that out of all the business strategies, only product differentiation, market development, business diversification and regrouping had positive significant effect on competitive advantage. Thus, the multiple regression model as previously expressed was changed to reflect reality as: $\mathrm{CA}=0.910+0.205 \mathrm{PD}+0.144 \mathrm{MD}+0.180 \mathrm{BD}+0.173 \mathrm{RG} \ldots . .$. eq.

This indicated that an increase in product differentiation, market development, business diversification and regrouping would lead to a subsequent increase in competitive advantage in selected flour milling companies.

\section{Discussion of Findings}

The findings indicated that business strategies affect firm's competitive advantage. Empirically, the result corroborates with the work of Galdeano-Gomez et al. (2008) on the nexus between strategies and competitive as interpreted through the eyes of product differentiation. Chiou et al. (2011) further sustained that strategies and progressive value addition enabled competitive advantage. Zhou and Wen (2019) position that business strategy strengthen competitive advantage was corroborated with current findings. Credence is added to Isiavwe et al. (2015) perspective that product differentiation enhances competitive advantage of firms. Nyaucho and Nyamweya (2015) also corroborated that differentiation influences drives operational excellence which is a parameter for competitive advantage, which Gregson and Andrew (2008) had established. The findings of this work are not in isolation, since Ordonez et al. (2018) had earlier established that competitive advantage is enthroned through strategies which this work subscribed. Also, Wijaya (2018) 
approach to market development and competitive advantage was substantiated and Akram et al. (2018) perspective on competitive advantage and strategy is sustained. Noe et al. (2017) was affirmed that business strategies have positive impact on competitive advantage, which Namada (2018) and Zikria et al. (2019) had established through product differentiation.

Lawal et al. (2016) and Kwayu et al. (2018) earlier works on business strategies and competitive advantage was also corroborated. Borda, Geleilate, Newburry and Kundu's (2017) work is confirmed that business diversification affects competitive advantage, which contradicted Namada (2018) that business diversification does not necessarily lead to competitve advantage. The hybridization of regrouping and backward integration is reinforced as Kwayu, Lal, and Abubakre (2018) demonstrated that it has positive significant effect on competitive advantage. Likewise, Ghiyasi's (2017) position was sustained that increased internal efficiency (regrouping) through waste elimination enabled competitive advantage. The differences in perspectives and conclusions resonate with the existing debate that context divergence and capability dissimilarity make achieving competitive advantage attributable to firms' specifics. The core thesis revolves around strategic approaches. The synergy achieved in the configuration of resources and strategies. Scholars (Gakuya \& Mbugua, 2018; Raj, 2018; Yoo, 2019) have emphasized this as firms' rivalary develop, deepen, and duplicate across the industry, each firm's strategic option will determine who leads. Theoretically, the findings supported dynamic capability theory that product differentiation, market development, business diversification.

Regrouping and backward integration can be employed both in the short term and long term to create and explain competitive advantage. The relevancy of this theory within context is that it focused on firms' ability to quickly self-fine-tune, calibrate, and align activities to environmental dictates in order to achieve competitive advantage. The self-alignment is intended to build strategic fit, transformation and leverage on strategic asset using diverse business strategies that would enable them to compete in a changing business environment.

\section{Conclusion and Recommendations}

This paper examined business strategies effect on competitive advantage with focus on selected flour mill companies in Lagos State, Nigeria. The results showed that business strategies (product differentiation, market development, business diversification, and regrouping) affected competitive advantage positively. However, the individual effect differs in terms of statistical significance, direction and relative effect. Product differentiation, market development, business diversification, and regrouping showed positive and significant effects on competitive advantage, leaving cost leadership and backward integration which showed negative significance on competitive advantage. Thus, the study concluded that organizations should focus on adopting product differentiation, geographical market expansion, and portfolio diversification, and regrouping. Though the findings cannot be generalized and its application in other sectors where competition is equally stiff, the adoption and utilization may require some level of caution. The researchers suggest that the application of the findings and recommendations of this study be limited to the flour mill industry in Nigeria, but with gradual adoption in the manufacturing sector in general. Further empirical survey on change adoption practices and competitiveness with infrastructure as moderator is inevitable for future researchers in the sector.

\section{References}

Akram, S. H., Sanaz, S. \& Mohammed, M. (2018). Competitive Advantage and Its impact on New Product Development Strategy (Case Study: Toos Nirro Technical Firm). Journal of Open Innovations: Technology, Market and Complexity, 4(17), 1-12.

Alkasim, S. B., Hilman, H., bin Bohari, A. M., Abdullah, S. S. \& Sallehddin, M. R. (2018). The mediating effect of cost leadership on the relationship between market penetration, market development, and firm performance. Journal of Business and Retail Management Research, 12(3).

Anyanwu, A. \& Umeh, C. (2019). Salesforce recruitment and commercial banks' sales growth: a study of fidelity bank plc. International Journal of Economics and Business Management, 5(1), 64-76. 
Araghi, N., Nikoomaram, H. \& Ghaffari, F. (2019). Optimized pricing decisions in a multi-level supply chain with various power and channel structures: A game-theoretic approach. International Journal of Industrial Mathematics, 11(2), 99-109.

Ariguzo, V. A., Egwakhe, A. J. \& Adefulu, A. (2019). Does Experience matter on export-preneurial bahaviours and business performance. International Journal of Research Science and Management, 6(3).

Aslam, H., Blome, C., Roscoe, S. \& Azhar, T. M. (2018). Dynamic supply chain capabilities: How market sensing, supply chain agility and adaptability affect supply chain.

Ahmad, N., Li, H. Z. \& Tian, X. L. (2019). Increased firm profitability under a nationwide environmental information disclosure program? Evidence from China. Journal of Cleaner Production, 230, 11761187.

Anwar, M. (2018). Business model innovation and SMEs performance-does competitive advantage mediate? International Journal of Innovation Management, 22(07), 185-357.

Axenbeck, J. (2019). Environmental innovation and firm profitability-An analysis with respect to firm size. ZEW-Centre for European Economic Research Discussion Paper, 19-033.

Bailey, B., Benson, A. J. \& Bruner, M. W. (2019). Investigating the organisational culture of CrossFit. International Journal of Sport and Exercise Psychology, 17(3), 197-211.

Bala, S. A. \& Alhassan, A. (2018). Structural effect of oil price shocks and food importation on economic growth in Nigeria using SVAR model. International Business and Accounting Research Journal, 2(1), 34-46.

Bryksina, N., Golovina, A. \& Legotin, F. (2018). Implementation of Cost Leadership Strategy by Russian Medical Companies of Laboratory Diagnostics Leadership for the Future Sustainable Development of Business and Education: Springer, 7(8), 189-198.

Bodhanwala, S. \& Bodhanwala, R. (2018). Does corporate sustainability impact firm profitability? Evidence from India. Management Decision, 56(8), 1734-1747.

Boddy, D., McCalman, J. \& Buchanan, D. A. (2018). The new management challenge: information systems for improved performance: Routledge, 7(6), 89-67.

Borda, A., Geleilate, J. M. G., Newburry, W. \& Kundu, S. K. (2017). Firm internationalization, business group diversification and firm performance: The case of Latin American firms. Journal of Business Research, 72, 104-113.

Bui, B. \& De Villiers, C. (2017). Business strategies and management accounting in response to climate change risk exposure and regulatory uncertainty. The British Accounting Review, 49(1), 4-24.

Camba-Mendez, G. \& Werner, T. (2017). The inflation risk premium in the post-Lehman period: ECB Working Paper, 56-98.

Cegarra-Navarro, J. G., Jiménez-Jiménez, D. \& Garcia-Perez, A. (2019). An integrative view of knowledge processes and a learning culture for ambidexterity: Towards improved organisational performance in the banking sector. IEEE Transactions on Engineering Management, (In-press), 67-89.

Cassia, F. \& Magno, F. (2019). A framework to manage business-to-business branding strategies. EuroMed Journal of Business, 8(6), 45-92.

Chiou, T. Y., Chan, H. K., Lettice, F. \& Chung, S. H. (2011). The influence of greening the suppliers and green innovation on environmental performance and competitive advantage in Taiwan. Transp. Res. Part E Logist, 47, 822-836.

Distanont, A. \& Khongmalai, O. (2018). The role of innovation in creating a competitive advantage. Kasetsart Journal of Social Sciences, 9(5), 68-92.

Egbo, P. (2018). Rentierism and Nigeria's Agricultural Sector: Southern Illinois University at Carbondale. Economics Research Journal, 4(8), 67-98.

Farzin, F., Yaghubipoor, A. \& Nekoui, M. H. (2017). Effects of the Manufacturing Execution Systems (MES) on Cost Leadership. Journal of Economic \& Management Perspectives, 11(3), 566-577.

FMN. (2019). Annaul Report 2019 Feeding the Nation Everyday. Lagos, Nigeria.

Gakuya, R. W. \& Mbugua, D. (2018). Effects of cost leadership strategy on customer loyalty among pharmaceutical companies in nairobi county, kenya. European Journal of Social Sciences Studies, 4(7), 56-88.

Ghiyasi, M. (2017). Inverse DEA based on cost and revenue efficiency. Computers \& Industrial Engineering, 114, 258-263.

Gregson, A. (2008). Pricing Strategies for Small Business Self Counsel Press. 
Guzman, M., Ocampo, J. A. \& Stiglitz, J. E. (2018). Real exchange rate policies for economic development. World Development, 110, 51-62.

González-Rodríguez, M. R., Jiménez-Caballero, J. L., Martín-Samper, R. C., Köseoglu, M. A. \& Okumus, F. (2018). Revisiting the link between business strategy and performance: Evidence from hotels. International Journal of Hospitality Management, 72, 21-31.

Giama, E., Mamaloukakis, M. \& Papadopoulos, A. M. (2019). Circularity in production process as a tool to reduce energy, environmental impacts and operational cost: The case of insulation materials. Paper presented at the 2019 4th International Conference on Smart and Sustainable Technologies (SpliTech), 6-14.

Geisler, E. \& Turchetti, G. (2018). Conduit versus content: a model of the firm's market involvement and organisational competitiveness. International Journal of Technology Management, 76(1-2), 137-162.

Galdeano-Gomez, E., Céspedes-Lorente, J. \& Martínez-del-Río, J. (2008). Environmental performance and spillover effects on productivity: Evidence from horticultural firms. Journal of Environmental Management, 88, 1552-1561.

Groves, R. M., Fowler, F. J., Couper, M. P., Lepkowski, J. M., Singer, E. \& Tourangeau, R. (2004). Survey Methodology. New York: Wiley.

Haseeb, M., Lis, M., Haouas, I. \& WW Mihardjo, L. (2019). The Mediating Role of Business Strategies between Management Control Systems Package and Firms Stability: Evidence from SMEs in Malaysia. Sustainability, 11(17), 4705.

Heeringa, S. G., West, B. T. \& Berglund, P. A. (2010). Applied Survey Data Analysis. Boca Raton: Chapman \& Hall/CRC.

Hunjra, A. I., Faisal, F. \& Gulshion, F. (2018). The Impact of Cost Leadership Strategy and Financial Management Control System on Organizational Performance: An Empirical Investigation of Pakistani Service Sector. The Lahore Journal of Business, Forthcoming, 5(7), 455-667.

Husgafvel, R., Linkosalmi, L., Hughes, M., Kanerva, J. \& Dahl, O. (2018). Forest sector circular economy development in Finland: A regional study on sustainability driven competitive advantage and an assessment of the potential for cascading recovered solid wood. Journal of Cleaner Production, 181, 483-497.

Ibidunni, O. S. (2009). Impact of competitive marketing on performance of multinational and Indigenous food and beverage manufacturing companies in Nigeria. A PhD thesis submitted to the Department of Business Studies, College of Business and Social Sciences Covenant University, Ota.

Isiavwe, D. T., Ogbari, M. E., Ogunnaike, O. O. \& Ade-Turton, D. (2015). The Role of Business Strategy in Accomplishing Organization Mission in Nigerian Manufacturing Companies. European Journal of Business and Management, 7(32), 120-127.

Jones, T. M., Harrison, J. S. \& Felps, W. (2018). How applying instrumental stakeholder theory can provide sustainable competitive advantage. Academy of Management Review, 43(3), 371-391.

Jyoti, J., Arora, H. \& Kour, S. (2017). Outsourcing and Organizational Performance: Role of Cost Leadership, Differentiation and Innovation Strategies. Sustainable Competitive Advantage: A Road to Success, 171.

Jensen, J., Rust, E. \& Mackool, S. (2018). Inflation, Interest Rates, and Equipment Finance: Anticipating and Adapting to a Changing Economic Environment. The Journal of Equipment Lease Financing (Online), 36(3), 1-5.

Kharub, M., Mor, R. S. \& Sharma, R. (2018). The relationship between cost leadership competitive strategy and firm performance: A mediating role of quality management. Journal of Manufacturing Technology Management, 5(7), 6-26.

Knottnerus, P. (2003). Sample Survey Theory. New York: Springer.

Kuik, O., Branger, F. \& Quirion, P. (2019). Competitive advantage in the renewable energy industry: Evidence from a gravity model. Renewable energy, 131, 472-481.

Kiprotich, E., Gachunga, H. \& Bonuke, R. (2018). Influence of Cost Leadership Procurement Strategy on Performance of Manufacturing Firms In Kenya. European Journal of Business and Strategic Management, 3(1), 32-51.

Kor, Y. Y. \& Mahoney, J. T. (2004). Edith Penrose's (1959) contributions to the resource-based view of strategic management. Journal of management studies, 41(1), 183-191.

Kwayu, S., Lal, B. \& Abubakre, M. (2018). Enhancing organisational competitiveness via social media-a strategy as practice perspective. Information Systems Frontiers, 20(3), 439-456. 
Lantos, G. P. (2001). The boundaries of strategic corporate responsibility. Journal of Consumer Marketing, 18(7), 595-632.

Lawal, F., Thompson, R. \& Thompson, E. (2016). Leadership Training at First Bank of Nigeria: A Case Study. Journal of Education and Learning, 5(2), 9-14.

Lawrence, J. M., Crecelius, A. T., Scheer, L. K. \& Patil, A. (2019). Multichannel Strategies for Managing the Profitability of Business-to-Business Customers. Journal of Marketing Research, 56(3), 479-497.

Mishra, D., Sharma, R., Gunasekaran, A., Papadopoulos, T. \& Dubey, R. (2019). Role of decoupling point in examining manufacturing flexibility: an empirical study for different business strategies. Total Quality Management \& Business Excellence, 30(9-10), 1126-1150.

Majid, A., Yasir, M., Yasir, M. \& Javed, A. (2019). Nexus of institutional pressures, environmentally friendly business strategies, and environmental performance. Corporate Social Responsibility and Environmental Management, 7(5), 445-667.

Mac Donagh, P., Velazco, S. J. E., Botta, G. F., Schlichter, T. \& Cubbage, F. (2019). Logging Contractors' Growth in the Southern Cone: An Analysis of Contractor Business Strategies, Innovation, and Mechanization. Forests, 10(1), 69.

Mu, L. (2018). On the Application of Overall Cost Leadership in Coal Enterprise Technological Innovation. Paper presented at the 8th International Conference on Social Network, Communication and Education (SNCE 2018).

Muda, I. \& Erlina, A. A. (2019). Influence of human resources to the effect of system quality and information quality on the user satisfaction of accrual-based accounting system. Contaduría y administración, 64(2), 10.

McKenney, S. \& Reeves, T. C. (2018). Conducting educational design research: Routledge, 6(4), 6-21.

MAN. (2019). Manufacturers can revive nigeria daily nigeria news Retrieved from https://www.manufacturersnigeria.org/ManInDailyNigerianNews.aspx.

Maury, B. (2018). Sustainable competitive advantage and profitability persistence: Sources versus outcomes for assessing advantage. Journal of Business Research, 84, 100-113.

Moravcikova, D., Krizanova, A., Kliestikova, J. \& Rypakova, M. (2017). Green Marketing as the Source of the Competitive Advantage of the Business. Sustainability, 9(12), 2218.

Namada, J. M. (2018). Organizational learning and competitive advantage Handbook of Research on Knowledge Management for Contemporary Business Environments, 86-104 IGI Global.

Nuryakin, U. M. Y. (2018). Competitive advantage and product innovation: Key success of Batik SMEs marketing performance in Indonesia. Academy of Strategic Management Journal, 17(2), 56-78.

Noe, R. A., Hollenbeck, J. R., Gerhart, B. \& Wright, P. M. (2017). Human resource management: Gaining a competitive advantage: McGraw-Hill Education New York, 225-667.

Nakatani, R. (2019). Firm performance and corporate finance in New Zealand. Applied Economics Letters, 26(13), 1118-1124.

Ngwakwe, C. \& Sebola, M. (2019). Differential effects of politically-driven policy uncertainty on exchange rate performance. African Journal of Public Affairs, 11(1), 34-47.

Nithisathian, K., Wall, W. P., Thanitnan, C. \& Ponwiritthon, R. (2018). Maintaining Indispensable Competitive Advantage: Corporate Strategy for 21st Century. RMUTL Journal of Business Administration and Liberal Arts, 6(1), 11-24.

Nyaucho, M. J. \& Nyamweya, I. N. (2015). Assessment of the effect of Cost Leadership Strategy on the performance of Liquefied Petroleum Gas Companies in Eldoret town, Uasin Gishu County, Kenya. International Journal of Business and Management Invention, 4(4), 1-7.

Obasaju, B. O., Olayiwola, W. K., Okodua, H. \& Adekunle, B. S. (2019). Regional economic integration and the backward integration of ECOWAS sub-region into global value chains. International Journal of Economic Policy in Emerging Economies, 12(3), 243-263.

Opolot, J. \& Mpagi, A. (2017). Inflation Dynamics in Uganda: The role of disequilibria in the money and traded goods markets. Journal of Statistical and Econometric Methods, 6(1), 45-74.

Olatunji, O. C. \& Oluwatoyin, A. E. (2019). Effect of Corporate Taxation on the Profitability of Firms in Nigeria. Journal of Economics and Behavioral Studies, 11(1(J)), 191-201.

Ordonez, M. S., Entrena, M. R., Cabrera, E. R. \& Henseler, J. (2018). Understanding product differentiation failures in agri-food markets: The role of product knowledge and brand credence in olive oil markets. Food quality and preference, 68, 146-155. 
Porter, M. E. (1980). Competitive Strategy: Techniques for Analyzing Industries and Competitors. New York: Free Press.

Porter, M. E. (1985). Competitive advantage: Creating and sustaining superior performance. New York: Free Press.

Pereira, E., Loureiro, I., Ribeiro, P., Costa, S., Costa, N. \& Arezes, P. M. (2019). Sustainable Business Strategies: What You Think Is What You Do? Occupational and Environmental Safety and Health, 747-755.

Pervan, M., Curak, M. \& Pavic Kramaric, T. (2018). The Influence of Industry Characteristics and Dynamic Capabilities on Firms' Profitability. International Journal of Financial Studies, 6(1), 4.

Qamri, G. M., Haq, M. A. U. \& Akram, F. (2015). The Impact of Inflation on Stock Prices: Evidence from Pakistan, 45-56.

Raj, K. (2018). A Critical Study on Business Strategies of 3i Infotech Ltd. International Journal of Case Studies in Business, IT and Education (IJCSBE), 2(1), 13-21.

Salazar-Ordóñez, M., Rodríguez-Entrena, M., Cabrera, E. R. \& Henseler, J. (2018). Understanding product differentiation failures: The role of product knowledge and brand credence in olive oil markets. Food quality and preference, 68, 146-155.

Sharma, A. \& Syam, N. (2018). Sales and customer development: An agenda for inquiry. Industrial Marketing Management, 69, 133-134.

Szymanski, E. M., Linkowski, D. C., Leahy, M. J., Diamond, E. E. \& Thoreson, R. W. (2019). Human resource development: An examination of perceived training needs of certified rehabilitation counselors. Journal of Applied Rehabilitation Counseling, 24(4), 58-70.

Tincani, M. \& Travers, J. (2018). Publishing single-case research design studies that do not demonstrate experimental control. Remedial and Special Education, 39(2), 118-128.

Wen, F., Xiao, J., Huang, C. \& Xia, X. (2018). Interaction between oil and US dollar exchange rate: nonlinear causality, time-varying influence and structural breaks in volatility. Applied Economics, 50(3), 319334.

Wijaya, A. J. (2018). Evaluasi Sistem Pengendalian Manajemen Berbasis Levers of Control untuk Menunjang Strategi Cost Leadership pada CV. BMT Surabaya, 78-97.

Wahal, S. (2019). The profitability and investment premium: Pre-1963 evidence. Journal of Financial Economics, 131(2), 362-377.

Yoo, C. S. (2019). Intellectual property and the economics of product differentiation Research Handbook on the Economics of Intellectual Property Law: Edward Elgar Publishing, 67-89.

Zhou, P. \& Wen, W. (2019). Carbon-constrained firm decisions: From business strategies to operations modeling. European Journal of Operational Research, 8(4),67-92.

Zikria, V., Takahashi, K. \& Maeda, K. (2019). International Competitiveness of Indonesia's Cocoa Sector: From the Viewpoint of Product Differentiation, Faculty of Agriculture Bulletin, Kyushu University, 8(5), 6795. 